\title{
ANALISIS MOTIVASI BELAJAR PESERTA DIDIK MELALUI PEMBERIAN REWARD DAN PUNISHMENT DI SDN NGARINGAN 05 KEC.GANDUSARI KAB.BLITAR
}

\author{
Yusvidha Ernata \\ Pendidikan Jasmani Kesehatan dan Rekreasi \\ Fakultas Pendidikan Ilmu Eksakta dan Keolahragaan \\ IKIP Budi Utomo Malang \\ Email: yusvidha_ernata@yahoo.co.id
}

\begin{abstract}
This study aims to analyze the motivation of learners through the provision of reward and punishment in SDN Ngaringan 05. This study used a descriptive quantitative approach. Number of samples 22 learners. Data obtained through the instruments developed researcher with the item number of instruments as much as 10 items. Measurement of the individual statements using a Likert scale, namely: 1) strongly disagree; 2) do not agree; 3) doubtful; 4) agree and 5) strongly agree. Data collection techniques used are questionnaires and interviews unstructured. The results showed that administration of reward and punisment can provide major influence on students' motivation. The right strategy will affect the learning process is increasing continuously achieve maximum results. To the teacher strives to motivate learners so that they are more interested in the learning process. One way to giving reward and punisment didactic. Demonstrated a high percentage of the results of research in which $73 \%$ of students feel happy if the work / tasks performed to get an award from $\mathrm{Mr} / \mathrm{Mrs}$ teacher. 59\% said it does not agree that there are learners who arrive late and often reprimanded Mr / Mrs teacher. 64\% of students agreed that learners feel embarrassed if too frequent violations.
\end{abstract}

Keywords: learning motivation, reward and punishmen

\begin{abstract}
ABSTRAK: Penelitian ini bertujuan untuk menganalisis motivasi belajar peserta didik melalui pemberian reward dan punishment di SDN Ngaringan 05. Penelitian ini menggunakan pendekatan kuantitatif jenis deskriptif. Jumlah sampel 22 peserta didik. Data diperoleh melalui instrumen yang dikembangkan peneliti dengan jumlah item instrumen sebanyak 10 item. Pengukuran terhadap masing-masing pernyataan menggunakan skala Likert, yaitu: 1) sangat tidak setuju; 2) tidak setuju; 3) ragu-ragu; 4) setuju dan 5) sangat setuju.Teknik pengumpulan data yang digunakan adalah angket dan wawancara tidak terstruktur. Hasil penelitian menunjukkan bahwa pemberian reward dan punisment dapat memberikan pengaruh besar terhadap motivasi belajar siswa. Strategi yang tepat akan mempengaruhi proses pembelajaran semakin meningkat secara terus menerus mencapai hasil yang maksimal. Untuk itu guru senantiasa berupaya memotivasi peserta didik agar mereka lebih tertarik untuk mengikuti proses pembelajaran. Salah satu caranya dengan cara memberikan reward dan punisment yang bersifat mendidik. Prosentase tinggi ditunjukkan dari hasil penelitian dimana $73 \%$ peserta didik merasa senang jika pekerjaan/tugas yang dilaksanakan mendapatkan penghargaan dari Bapak/Ibu Gurunya. 59\% menyatakan sangat tidak setuju jika peserta didik ada yang datang terlambat dan sering mendapat teguran dari Bapak/Ibu guru. 64\% siswa menyatakan setuju bahwa peserta didik merasa malu jika terlalu sering melakukan pelanggaran.
\end{abstract}

Kata kunci : motivasi belajar, reward dan punishmen

\section{PENDAHULUAN}

Pendidikan merupakan salah satu hal terpenting dalam kehidupan, ini berarti bahwa setiap manusia berhak mendapat dan berharap untuk selalu berkembang dalam pendidikan. Peningkatan kualitas pendidikan baik secara kualitatif maupun kuantitatif harus dilakukan secara terus menerus, sehingga pendidikan dapat digunakan sebagai wahana dalam membangun watak bangsa
( Mulyasa, 2007). Hal ini sesuai dengan UU No. 20 tahun 2003 tentang Sistem Pendidikan Nasional, pendidikan adalah usaha sadar dan terencana untuk mewujudkan suasana belajar dan proses pembelajaran agar peserta didik secara aktif mengembangkan potensi dirinya untuk memiliki kekuatan spiritual keagamaan, pengendalian diri, kepribadian, kecerdasan, akhlak mulia, serta keterampilan yang diperlukan 
dirinya, masyarakat, bangsa dan negara. Lembaga pendidikan mempunyai peran penting dalam peningkatan sumber daya manusia. Sehingga dengan segala upaya orang tua berkewajiban untuk menyekolahkan putra putrinya hingga jenjang yang lebih tinggi. Hal ini bisa dilihat pada setiap ajaran baru, jumlah peserta didik baru semakin meningkat dari tiap tahunnya. Melihat kondisi yang demikian tidak menutup kemungkinan timbul berbagai masalah yang dihadapi oleh para guru. Keberhasilan pelaksanaan pendidikan terutama ditentukan oleh faktor guru (Ibrahim, 2004).Dimana jika melihat pendidikan sekarang ini yang berhubungan dengan tingkah laku peserta didik, banyak terjadi penyimpangan dan pelanggaran yang tidak sesuai dengan harapan. Misalnya perkelahian antar peserta didik, terlambat masuk sekolah, melalaikan tugas, gaduh pada saat jam pelajaran, membantah jika diperingatkan, merokok dan lain sebagainya. Hal yang demikian tidak hanya terjadi di lingkungan SDN Ngaringan 05 akan tetapi hampir di semua lembaga sekolah lainnya.

Penyimpangan lain dari peserta didik dalam kegiatan belajar mengajar yaitu sering tidak fokus dan tidak memperhatikan pada pelajaran yang disampaikan oleh guru saat mengajar di depan kelas. Melihat keadaan yang demikian seorang guru harus mengusai kelas dan mengkondisikan peserta didik yang perhatiannya mulai terpecah. Sebagai seorang guru haruslah mampu memberikan motivasi pada peserta didik, bagaimana caranya bahwa belajar itu tidak membosankan melainkan menyenangkan. Suasana belajar yang tidak nyaman dan membosankan, karena dalam kegiatan belajar mengajar lebih banyak menggunakan metode ceramah yang monoton. Untuk mengatasi masalah tersebut serta mampu memberi motivasi belajar bagi peserta didik agar proses pendidikan bisa berjalan dengan lancar dan berhasil, maka diadakan upaya pencegahan dalam berbagai macam seperti peraturan-peraturan.Peraturan itu harus ditaati dan dilaksanakan oleh peserta didik demi meningkatkan kualitas dan prestasi belajar peserta didik.
Berdasarkan latar belakang yang telah diuraikan di atas maka rumusan masalah dalam penelitian ini adalah; 1) Sejauh mana pemberian reward dan punishmentberpengaruh terhadap motivasi belajar peserta didik kelas $\mathrm{V}$ di SDN Ngaringan 05 ?; 2) Seberapa besar peningkatan motivasi belajar peserta didik setelah reward dan punisment diterapkan.

\section{Motivasi Belajar}

Motivasi dan belajar merupakan dua hal yang saling mempengaruhi. Namun, sebelum membahas lebih jauh tentang motivasi belajar maka perlulah dibedakan dahulu antara pengertian motivasi dan pengertian belajar. Istilah motivasi berasal dari kata motif yang dapat diartikan sebagai kekuatan yang terdapat dalam diri individu, yang menyebabkan individu tersebut bertindak atau berbuat. Motif adalah daya penggerak dalam diri seseorang untuk melakukan aktivitas tertentu, demi mencapai tujuan tertentu. Dengan demikian, motivasi merupakan dorongan yang terdapat dalam diri seseorang untuk berusaha mengadakan perubahan tingkah laku yang lebih baik dalam memenuhi kebutuhannya. Kedua hal tersebut merupakan daya upaya yang mendorong seseorang untuk melakukan sesuatu. Setelah mengetahui pengertian dari motif dan motivasi, berikut ada beberapa pendapat mengenai pengertian motivasi. Dalam motivasi terkandung keinginan yang mengaktifkan, menggerakkanmenyalurkan, dan mengarahkan sikap dan perilaku individu belajar. Menurut Muhibbin Syah (2008) motivasi ialah keadaan internal organisme baik manusia ataupun hewan yang mendorongnya untuk berbuat sesuatu. Dalam pengertian ini, motivasi berarti pemasok daya (energizer) untuk bertingkah laku secara terarah.Menurut Sardiman (2007) motivasi dapat juga dikatakan serangkaian usaha untuk menyediakan kondisi-kondisi tertentu, sehingga seseorang mau dan ingin melakukan sesuatu, dan bila ia tidak suka, maka akan berusaha untuk meniadakan atau mengelakkan perasaan tidak suka itu. 
Berdasarkan beberapa pengertian di atas dapat disimpulkan bahwa yang dimaksud dengan motivasi adalah dorongan yang terdapat dalam diri seseorang untuk melakukan aktivitas tertentu untuk mencapai suatu tujuan.

Sedangkan istilah belajar menurut Slameto (2010) belajar adalah suatu proses usaha yang dilakukan seseorang untuk memperoleh suatu perubahan tingkah laku yang baru secara keseluruhan sebagai pengalamannya sendiri dalam interaksi dengan lingkungannya. Namun pandangan setiap orang berbeda dalam mengartikan belajar sehingga berpengaruh terhadap tindakan atau perbuatan yang ditimbulkan. Menurut Sanjaya (2006) dalam suatu proses belajar pasti terdapat kegiatan mengajar, secara deskriptif mengajar diartikan sebagai proses penyampaian informasi atau pengetahuan dari guru kepada peserta didik. Menurut Purwanto (2004) belajar merupakan suatu perubahan tingkah laku yang terjadi melalui latihan atau pengalaman dimana perubahan yang terjadi relatif menetap serta menyangkut kepribadian baik fisik maupun psikis.

Berdasarkan penjelasan tentang pengertian motivasi dan belajar tersebut di atas maka dapatlah dikemukakan pengertian motivasi belajar adalah keseluruhan daya penggerak psikis di dalam diri peserta didik yang menimbulkan kegiatan belajar, menjamin kelangsungan kegiatan belajar dan memberikan arah pada kegiatan belajar itu demi mencapai suatu tujuan.Menurut Hamzah (2007) motivasi belajar adalah dorongan internal dan eksternal pada peserta didik-peserta didik yang sedang belajar untuk mengadakan perubahan tingkah laku. Berdasarkan pengertian di atas dapat disimpulkan bahwa motivasi dapat dipandang sebagai fungsi, berarti motivasi berfungsi sebagai daya penggerak dari dalam individu untuk melakukan aktivitas tertentu dalam mencapai tujuan. Motivasi dipandang dari segi proses, berarti motivasi dapat dirangsang oleh faktor luar, untuk menimbulkan motivasi dalam diri peserta didik yang melalui proses rangsangan belajar sehingga dapat mencapai tujuan yang di kehendaki. Motivasi dipandang dari segi tujuan, berarti motivasi merupakan sasaran stimulus yang akan dicapai. Jika seorang mempunyai keinginan untuk belajar suatu hal, maka dia akan termotivasi untuk mencapainya.

Macam-macam motivasi belajar di sekolah dapat dibedakan menjadi beberapa bentuk. Pertama, Motivasi intrinsik. Motivasi intrinsik menurut Sardiman (2007) adalah motif-motif yang menjadi aktif atau berfungsinya tidak perlu rangsangan dari luar, karena dalam diri setiap individu sudah ada dorongan untuk melakukan sesuatu. Motivasi ekstrinsik yaitu motif-motif yang aktif dan berfungsinya karena adanya perangsangan dari luar.Menurut Hamalik (2006) motivasi intrinsik adalah hal dan keadaan yang berasal dari dalam diri peserta didik sendiri yang dapat mendorongnya melakukan tindakan belajar.Berdasarkan uraian di atas jelaslah bahwa motivasi mendorong timbulnya kelakuan dan mempengaruhi serta mengubah kelakuan. Jadi, fungsi motivasi itu meliputi berikut ini:a) Mendorong timbulnya kelakuan atau suatu perbuatan. Tanpa motivasi maka tidak akan timbul sesuatu perbuatan seperti belajar; b) Motivasi berfungsi sebagai pengarah,artinya mengarahkan pebuatan kepada pencapaian tujuan yang diinginkan; c) Motivasi berfungsi sebagai penggerak, diibaratkan Ia berfungsi sebagai mesin bagi mobil. Besar kecilnya motivasi akan menentukan cepat atau lambatnya suatu pekerjaan. Motivasi itu berkaitan erat dengan suatu tujuan, suatu cita-cita. Semakin berharga tujuan itu bagi yang bersangkutan makin kuat pula motivasinya.

Menurut Purwanto (2004) fungsi dari motivasi yaitu: a) Mendorong manusia untuk berbuat. Motivasi berfungsi sebagai penggerak atau sebagai motor yang memberikan kekuatan kepada seseorang untuk melakukan suatu tugas; b) Motivasi itu menentukan arah perbuatan, yaitu kearah perwujudan suatu tujuan cita-cita. Motivasi mencegah penyelewengan di jalan yang harus ditempuh untuk mencapai tujuan itu. Makin jelas tujuan itu, makin jelas pula terbentang jalan yang harus ditempuh; c) Motivasi itu 
menyeleksi perbuatan,artinya menentukan perbuatan-perbuatan mana yang dilakukan, yang serasi guna mencapai tujuan itu dengan mengesampingkan perbuatan yang tidak bermanfaat bagi tujuan yang diharapkan.

\section{Reward dan Punishment}

Reward dan punishment adalah salah satu teori belajar yang berusia paling muda. Penciptanya bernama Burrhus Fredric Skinner (1904) seorang psikolog terkemuka dari Harvard University seorang penganut paham behaviorisme yang dianggap kontroversial, karena jika direnungkan dan dibandingkan dengan teori dan juga temuan riset psikologi kognitif, karakteristik yang terdapat dalam teoriteori behaviorisme tersebut mengandung banyak kelemahan. Dalam teori ini diambil dari percobaannya yang kemudian dikenal dengan istilah Operant Conditioning (pembiasaan perilaku respon). Tingkah laku pada dasarnya merupakan fungsi dari konsekuensi tingkah laku itu sendiri, apabila munculnya tingkah laku diikuti dengan sesuatu yang menyenangkan (reward), maka tingkah laku tersebut cenderung untuk diulang. Sebaliknya, jika munculnya tingkah laku diikuti dengan sesuatu yang tidak meyenangkan (punishment), maka tingkah laku tersebut cenderung tidak akan diulang (Maksum dalam Sudirman, 2007).

Menurut Purwanto (2006) reward adalah sebagai alat untuk mendidik anak supaya anak dapat merasa senang karena perbuatan atau pekerjaannya mendapat penghargaan. Reward merupakan segala yang diberikan guru berupa penghargaan yang menyenangkan perasaan yang diberikan kepada peserta didik atas dasar hasil baik yang telah dicapai dalam proses pendidikan dengan tujuan memberikan motivasi kepada peserta didik, agar dapat melakukan perbuatan terpuji dan berusaha untuk meningkatkannya. Menurut Djaali (2012) reward menggunakan seluruh situasi yang memotivasi, mulai dari dorongan biologis yang merupakan kebutuhan utama seseorang sampai pada hasil-hasil yang memberikan ganjaran bagi seseorang, misalnya uang, perhatian, afeksi dan aspirasi sosial tingkat tinggi. Jadi reward merupakan alat pendidikan yang menyenangkan, reward juga dapat menjadi pendorong atau motivasi bagi peserta didik untuk belajar lebih baik lagi. Contoh konkret reward yaitu Seorang guru hendaknya merespon apa yang dilakukan peserta didik seperti pujian yang mendidik, memberi hadiah, mendoakan, menepuk pundak, apabila peserta didik telah melakukan sesuatu yang baik, atau telah berhasil mencapai sebuah tahap perkembangan tertentu, atau tercapainya sebuah target.

Punishment adalah usaha edukatif untuk memperbaiki dan mengarahkan peserta didik kearah yang benar, bukan praktik hukuman dan siksaan yang memasung kreativitas. Melainkan, hukuman yang dilakukan harus bersifat pedagogies, yaitu untuk memperbaiki dan mendidik ke arah yang lebih baik (Fadjar, 2005). Berdasarkan pengertian diatas, punishment yang diberikan bukan untuk balas dendam kepada peserta didik melainkan untuk memperbaiki tingkah laku peserta didik yang kurang baik ke arah yang lebih baik dan dapat memberikan motivasi belajar peserta didik. Punishment merupakan imbalan dari perbuatan- perbuatan yang tidak baik atau mengganggu jalannya proses pendidikan. Dapat dikatakan juga bahwa punishment adalah penilaian kegiatan belajar murid yang bersifat negatif, sedang reward adalah penilaian yang bersifat positif. Contoh konkret punishment seperti menasehati, memberi arahan, melarang melakukan sesuatu, menegur, membentak, memukul tidak keras, bahkan meminta wali murid memberi sanksi. Dengan demikian, reward dan punishment, di samping berfungsi sebagai alat-alat pendidikan, maka sekaligus berfungsi sebagai motivasi belajar murid. Motivasi adalah keadaan dalam pribadi orang yang mendorong individu yang melakukan aktivitas-aktivitas tertentu guna mencapai sesuatu tujuan (Suryabrata, 2005).

Menurut Uno (2007) Motivasi belajar adalah dorongan internal dan eksternal pada peserta didik-peserta didik yang sedang belajar untuk mengadakan perubahan tingkah laku. Motivasi dapat 
berfungsi sebagai pendorong usaha dan pencapaian prestasi. Adanya motivasi yang baik dalam belajar akan menunjukkan hasil yang baik. Upaya yang tekun dan terutama didasari adanya motivasi, maka seseorang yang belajar akan dapat melahirkan pretasi yang baik (Sardiman, 2007). Berdasarkan uraian di atas dapat diketahui bahwa reward dan punishment di samping sebagai alat pendidikan juga sebagai alat motivasi bagi peserta didik dalam mencapai prestasi belajar peserta didik setinggitingginya. Untuk itu diperlukan adanya pemberian reward dan punishment disekolah-sekolah.

SDN Ngaringan 05 adalah salah satu lembaga pendidikan formal di Kabupaten Blitar, terletak di bawah kaki gunung Kelud kabupaten Blitar, meskipun di SDN Ngaringan 05 tidak menerapkan sistem full day school seperti sebagian besar sekolahsekolah di kota, akan tetapi tidak menutup kemungkinan peserta didik akan merasa bosan pada pelajaran yang setiap hari diajarkan di sekolah. Dengan memberikan reward dan punishment, kegiatan belajar menjadi lebih menyenangkan, terkendali, dan bervariasi.Mengingat pentingnya pemberian reward dan punishment di sekolah, maka terdapat keinginan melakukan penelitian tentang analisis motivasi belajar peserta didik melalui pemberian reward dan punishment. Reward dan punishment merupakan suatu bentuk teori penguatan positif yang bersumber dari teori behavioristik. Menurut teori behavioristik belajar adalah perubahan tingkah laku sebagai akibat dari adanya interaksi antara stimulus dan respon. Belajar merupakan bentuk perubahan yang dialami peserta didik dalam hal kemampuannya untuk bertingkah laku dengan cara yang baru sebagai hasil interaksi antara stimulus dan respon (Budiningsih, 2005).

Peranan reward dalam proses pengajaran cukup penting terutama sebagai faktor eksternal dalam mempengaruhi dan mengarahkan perilaku peserta didik. Hal ini berdasarkan atas berbagai pertimbangan logis, diantaranya reward biasanya dapat menimbulkan motivasi belajar peserta didik dan reward memiliki pengaruh positif dalam kehidupan peserta didik. Reward merupakan alat pendidikan yang mudah dilaksanakan dan dapat menyenangkan para peserta didik, untuk itu reward dalam suatu proses pendidikan dibutuhkan keberadaannya demi meningkatkan motivasi belajar peserta didik. Maksud dari pendidik memberi reward kepada peserta didik adalah supaya peserta didik menjadi lebih giat lagi usahanya untuk memperbaiki prestasi yang telah dicapainya, dengan kata lain peserta didik menjadi lebih keras kemauannya untuk belajar lebih baik. Reward yang diberikan kepada peserta didik bentuknya bermacammacam. Menurut Sardiman (2007) reward dapat dibedakan menjadi empat macam, yaitu: a) Pemberian angka atau nilai, angka sebagai simbol kegiatan belajar, angka yang dimaksud adalah bonus nilai/tambahan nilai bagi peserta didik yang mengerjakan tugas dengan baik; b) Pemberian hadiah, reward berbentuk hadiah disini adalah pemberian berupa barang. Reward berupa pemberian barang ini disebut juga reward materiil, yaitu hadiah yang terdiri dari alat-alat keperluan sekolah, seperti pensil, penggaris, buku dan lain sebagainya; c) Pemberian pujian akan memupuk suasana yang menyenangkan dan mempertinggi gairah belajar serta sekaligus akan membangkitkan harga diri peserta didik sehingga prestasi belajar peserta didik ikut meningkat.

Dalam memberikan reward seorang guru hendaknya dapat mengetahui siapa yang berhak mendapatkan reward, seorang guru harus selalu ingat akan maksud reward itu. Seorang peserta didik yang pada suatu ketika menunjukkan hasil lebih baik dari pada biasanya, mungkin sangat baik diberi reward.Dalam hal ini seorang guru hendaklah bijaksana, jangan sampai reward menimbulkan iri hati pada peserta didik yang lain yang merasa dirinya lebih pandai, tetapi tidak mendapat reward.Setelah memperhatikan uraian tentang maksud reward, serta macammacam reward yang baik diberikan kepada peserta didik, ternyata bukanlah soal yang mudah. Menurut Purwanto(2006) ada beberapa syarat 
yang harus diperhatikan oleh seorang guru sebelum memberikan reward pada peserta didik, yaitu: a) Untuk memberi reward yang pedagogis perlu sekali guru benar- benar mengenal peserta didiknya dan tahu menghargai dengan tepat. Reward dan penghargaan yang salah dan tidak tepat dapat membawa akibat yang tidak diinginkan; b) Reward yang diberikan kepada seorang peserta didik janganlah hendaknya menimbulkan rasa cemburu atau iri hati bagi peserta didik lain yang merasa pekerjaannya juga lebih baik, tetapi tidak mendapat reward; c) Memberi reward hendaklah hemat, terlalu sering atau terus menerus memberi reward akan menjadi hilang arti reward itu sebagai alat pendidikan; d) Janganlah memberi reward dengan menjanjikan terlebih dahulu sebelum peserta didik menunjukkan prestasi kerjanya apalagi bagi reward yang diberikan kepada seluruh kelas. Rewardyang telah dijanjikan lebih dahulu hanyalah akan membuat peserta didik terburu-buru dalam bekerja dan akan membawa dalam kesukaran bagi beberapa peserta didik yang kurang pandai;e) Pendidik harus berhati-hati memberikan reward, jangan sampai reward yang diberikan pada peserta didik diterima sebagai upah dari jerih payah yang telah dilakukannya.

Lebih lanjut Purwanto (2006) berpendapat bahwa sebagian ahli pendidikan menyetujui dan menganggap penting reward dipakai sebagai alat untuk membentuk kata hati peserta didik. Sebaliknya ada pula ahli-ahli pendidikan yang tidak suka sama sekali menggunakan reward. Mereka berpendapat bahwa reward itu dapat menimbulkan persaingan yang tidak sehat pada peserta didik. Menurut pendapat mereka, seorang guru hendaklah mendidik peserta didik supaya mengerjakan dan berbuat yang baik dengan tidak mengharapkan pujian atau reward tetapi semata-mata karena pekerjaan atau perbuatan itu memang kewajibannya.Menurut Purwanto (2006) reward adalah alat yang mendidik, maka dari itu reward tidak boleh berubah sifatnya menjadi upah. Upah adalah sesuatu yang mempunyai nilai sebagai ganti rugi dari suatu pekerjaan atau suatu jasa. Upah adalah sebagai pembayar suatu tenaga, pikiran, atau pekerjaan yang telah dilakukan seseorang. Sedangkan reward sebagai alat pendidikan tidaklah demikian, untuk itu seorang guru harus selalu ingat maksud dari pemberian reward itu.

Tujuan yang harus dicapai dalam pemberian reward adalah untuk lebih mengembangkan motivasi yang bersifat intrinsik dari motivasi ektrinsik, dalam artian peserta didik melakukan suatu perbuatan, maka perbuatan itu timbul dari kesadaran peserta didik itu sendiri. Dengan reward itu, juga diharapkan dapat membangun suatu hubungan yang positif antara guru dan peserta didik, karena reward itu adalah bagian dari pada penjelmaan rasa cinta kasih sayang seorang guru kepada peserta didik.

Jadi, maksud dari reward yang terpenting bukanlah hasil yang dicapai seorang peserta didik, tetapi dengan hasil yang dicapai peserta didik, guru bertujuan membentuk kata hati dan kemauan yang lebih baik dan lebih keras pada peserta didik. Seperti halnya telah disinggung di atas, bahwa reward di samping merupakan alat pendidikan represif yang menyenangkan, reward juga dapat menjadi pendorong atau motivasi bagi peserta didik untuk belajar lebih baik lagi.

\section{Seperti}

halnya reward,punishment diberikan sebagai usaha mengembalikan peserta didik ke arah yang baik dan memotivasinya menjadi pribadi yang imajinatif, kreatif dan produktif. Punishment sebagai alat pendidikan, meskipun mengakibatkan penderitaan bagi peserta didik yang dihukum, namun dapat juga menjadi alat motivasi, alat pendorong untuk mempergiat aktivitas belajar peserta didik (meningkatkan motivasi belajar peserta didik). Ia berusaha untuk dapat selalu memenuhi tugas-tugas belajarnya, agar terhindar dari bahaya hukuman. Dengan adanya punishment itu diharapkan supaya peserta didik dapat menyadari kesalahan yang diperbuatnya, sehingga peserta didik jadi berhati-hati dalam mengambil tindakan.Punishment bisa dikatakan berhasil apabila dapat menimbulkan perasaan penyesalan akan perbuatan yang telah dilakukannya. Di samping itu 
menurut Purwanto (2006) punishment juga mempunyai dampak, yaitu: a) Menimbulkan perasaan dendam pada si terhukum. Ini adalah akibat dari hukuman sewenang-wenang dan tanpa tanggung jawab; b) Menyebabkan peserta didik menjadi lebih pandai menyembunyikan pelanggaran; c) Dapat memperbaiki tingkah laku si pelanggar; d) Mengakibatkan si pelanggar menjadi kehilangan perasaan salah, oleh karena kesalahannya dianggap telah dibayar dengan punishment yang telah dideritanya; e) Akibat yang lain adalah memperkuat kemauan si pelanggar untuk menjalankan kebaikan.

Punishment merupakan

alat pendidikan yang tidak menyenangkan, bersifat negatif, namun demikian dapat juga menjadi motivasi, alat pendorong untuk mempergiat belajarnya peserta didik. Peserta didik yang pernah mendapat punishment karena tidak mengerjakan tugas, maka ia akan berusaha untuk tidak memperoleh punishment lagi. Ia berusaha untuk dapat selalu memenuhi tugas-tugas belajarnya agar terhindar dari bahaya punishment. Hal ini berarti bahwa ia didorong untuk selalu belajar. Dalam dunia pendidikan, menerapkan punishment tidak lain hanyalah untuk memperbaiki tingkah laku peserta didik untuk menjadi lebih baik. Punishment disini sebagai alat pendidikan untuk memperbaiki pelanggaran yang dilakukan peserta didik bukan untuk balas dendam. Menurut Purwanto (2006) supaya punishment bisa menjadi alat pendidikan, maka seorang guru sebelum memberikan punishment pada peserta didik yang melakukan pelanggaran sebaiknya guru memperhatikan syaratsyarat punishment yang bersifat pedagogis sebagai berikut; a) Tiap-tiap punishment hendaknya dapat dipertanggung jawabkan. Ini berarti punishment itu tidak boleh sewenangwenang; b)Punishment itu sedapatdapatnya bersifat memperbaiki;c) Punishment tidak boleh bersifat ancaman atau pembalsan dendam yang bersifat perseorangan; d) Jangan menghukum pada waktu sedang marah; e) Tiap-tiap punishment harus diberikan dengan sadar dan sudah diperhitungkan dan dipertimbangkan terlebih dahulu; f) Bagi si terhukum (peserta didik), punishment itu hendaklah dapat dirasakan sendiri sebagai kedukaan atas penderitaan yang sebenarnya; g) Jangan melakukan hukuman badan sebab pada hakikatnya punishment badan itu dilarang oleh Negara; h) Punishment tidak boleh merusakkan hubungan baik antara si pendidik dan peserta didik; i) Adanya kesanggupan memberi maaf dari si pendidik, sesudah menjatuhkan punishment dan setelah itu peserta didik menginsafi kesalahannya. Terdapat beberapa macam punishment yang dapat diberikan kepada peserta didik. Pertama, Punishment preventif, yaitu punishment yang dilakukan dengan maksud agar tidak atau jangan terjadi pelanggaran. Punishment ini bermaksud untuk mencegah jangan sampai terjadi pelanggaran sehingga hal itu dilakukannya sebelum pelanggaran dilakukan (Purwanto, 2006).

Punishment ini dilakukan setelah terjadi pelanggaran atau kesalahan (Purwanto, 2006). Punishment badan yang membahayakan bagi peserta didik tidak sepantasnya diberikan dalam dunia pendidikan, karena punishment semacam ini tidak mendorong peserta didik untuk berbuat sesuai dengan kesadarannya. Sehingga peserta didik trauma maka peserta didik tidak akan mau untuk belajar bahkan akan minta berhenti dari sekolah. Apabila seorang guru ingin sukses di dalam pengajaran, guru harus memikirkan setiap murid dan memberikan punishment yang sesuai menimbang-nimbang kesalahannya dan setelah mengetahui latar belakangnya. Sehubungan dengan punishment yang dijatuhkan kepada peserta didik, maka tujuan yang ingin dicapai sesekali bukanlah untuk menyakiti atau untuk menjaga kehormatan guru atau sebaliknya agar guru itu ditaati oleh peserta didik, akan tetapi tujuan punishment yang sebenarnya adalah agar peserta didik yang melanggar merasa jera dan tidak akan mengulangi lagi.

Tujuan pemberian punishment ada dua macam, yaitu tujuan dalam jangka pendek dan tujuan jangka panjang. Tujuan dalam jangka pendek adalah untuk menghentikan tingkah laku yang 
salah, sedangkan tujuan dalam jangka panjang adalah untuk mengajar dan mendorong peserta didik agar dapat menghentikan sendiri tingkah lakunya yang salah. Setelah mengetahui tujuan dari punishment dalam pendidikan di atas maka kita harus mengetahui punishment yang cocok untuk diterapkan dalam dunia pendidikan.

\section{METODE PENELITIAN}

Pendekatan penelitian yang digunakan pada penelitian ini adalah kuantitatif dengan jenis penelitian deskriptif, karena penelitian ini bersifat mengidentifikasi permasalahan yang ada. Lokasi yang digunakan adalah SDN Ngaringan 05 Kabupaten Blitar. Waktu yang digunakan dalam penelitian ini yaitu pada bulan April 2016. Adapun sampel yang diteliti adalah 22 peserta didik kelas $\mathrm{V}$ di SDN Ngaringan 05. Teknik pengumpulan data yang akan digunakan dalam penelitian ini adalah angket dan wawancara. Angket yang dibagikan dalam bentuk pertanyaan merupakan angket semi tertutup, dimana dalam angket tersebut sudah disediakan jawaban sehingga responden tinggal memilih jawabannya. Jawaban setiap item pada angket memiliki bobot skor sangat setuju $=5$; setuju $=4$; ragu-ragu $=3$; tidak setuju $=2 ;$ sangat tidak setuju $=1$. Sedangkan teknik wawancara yang digunakan dalam penelitian ini adalah wawancara tidak terstruktur. Wawancara tidak terstruktur adalah wawancara bebas dimana peneliti tidak menggunakan pedoman wawancarayang telah disusun secara sistematis dan lengkap untuk pengumpulan datanya.

\section{HASIL DAN PEMBAHASAN}

Pemberian reward memotivasi belajar peserta didik.Ditunjukkan pada tabel 1, respon peserta didik terhadap pemberian reward terdiri dari 5 option yaitu sangat setuju, setuju, ragu-ragu, tidak setuju, sangat tidak setuju. Disertai beberapa pernyataan yang diuraikan dalam tabel.

Dimensi pertama ini, respon terhadap reward yang diberikan memiliki pengaruh terhadap peningkatan motivasi belajar pada peserta didik. Dimana item yang menunjukkan peserta didik termotivasi dengan adanya reward yaitu: a) $73 \%$ peserta didik merasa senang jika pekerjaan/tugas yang dilaksanakan mendapatkan penghargaan dari Bapak/Ibu Gurunya; b) 32\% peserta didik merasa penghargaan yang diberikan oleh Bapak/Ibu Guru bisa memberikan motivasi pada diri peserta didik; d) hampir mayoritas peserta didik merasa tidak setuju bahkan sangat tidak setuju, apabila setiap pekerjaan/tugas yang dilakukan oleh peserta didik tidak ada respon dari Bapak/lbu Gurunya. Tabel 1

Respon peserta didik terhadap reward yang

\begin{tabular}{|c|c|c|c|c|c|c|c|}
\hline \multirow{2}{*}{ No } & \multirow{2}{*}{ Pernyataan } & SS & $\mathbf{S}$ & $\mathbf{R}$ & TS & $\begin{array}{c}\text { ST } \\
\text { S }\end{array}$ & \multirow{2}{*}{$\begin{array}{c}\text { Rata } \\
- \\
\text { rata }\end{array}$} \\
\hline & & 5 & 4 & 3 & 2 & 1 & \\
\hline \multirow[t]{2}{*}{1} & \multirow[b]{2}{*}{$\begin{array}{l}\text { Saya merasa } \\
\text { senang } \\
\text { pekerjaan/tugas } \\
\text { yang saya lakukan } \\
\text { mendapatkan } \\
\text { penghargaan yang } \\
\text { positif dari Bapak } \\
\text { / Ibu Guru }\end{array}$} & 16 & 6 & 0 & 0 & 0 & \multirow[t]{2}{*}{20.8} \\
\hline & & $\begin{array}{l}73 \\
\%\end{array}$ & $\begin{array}{l}27 \\
\%\end{array}$ & $\begin{array}{l}0 \\
\%\end{array}$ & $\begin{array}{l}0 \\
\%\end{array}$ & $0 \%$ & \\
\hline \multirow[t]{3}{*}{2} & \multirow{3}{*}{$\begin{array}{l}\text { Saya merasa } \\
\text { senang diberi } \\
\text { kesempatan } \\
\text { menunjukkan } \\
\text { bakat dan } \\
\text { kemampuan saya }\end{array}$} & 4 & 18 & 0 & 0 & 0 & \multirow[t]{3}{*}{18.4} \\
\hline & & 18 & 82 & 0 & 0 & $0 \%$ & \\
\hline & & $\%$ & $\%$ & $\%$ & $\%$ & & \\
\hline \multirow[t]{3}{*}{3} & \multirow{3}{*}{$\begin{array}{l}\text { Saya merasa } \\
\text { senang dengan } \\
\text { prestasi yang saya } \\
\text { peroleh }\end{array}$} & 4 & 16 & 2 & 0 & 0 & \multirow[t]{3}{*}{18} \\
\hline & & 18 & 73 & 9 & 0 & $0 \%$ & \\
\hline & & $\%$ & $\%$ & $\%$ & $\%$ & & \\
\hline \multirow[t]{3}{*}{4} & \multirow{3}{*}{$\begin{array}{l}\text { Penghargaan dari } \\
\text { Bapak Ibu Guru } \\
\text { memberi motivasi } \\
\text { pada diri saya } \\
\text { untuk } \\
\text { meningkatkan } \\
\text { prestasi belajar }\end{array}$} & 7 & 15 & 0 & 0 & 0 & \multirow[t]{3}{*}{19} \\
\hline & & 32 & 68 & 0 & 0 & $0 \%$ & \\
\hline & & $\%$ & $\%$ & $\%$ & $\%$ & & \\
\hline \multirow[t]{3}{*}{5} & \multirow{3}{*}{$\begin{array}{l}\text { Saya senang } \\
\text { semua Bapak Ibu } \\
\text { Guru senantiasa } \\
\text { memberikan } \\
\text { penghargaan di } \\
\text { setiap pekerjaan } \\
\text { yang saya lakukan }\end{array}$} & 5 & 18 & 0 & 0 & 0 & \multirow[t]{3}{*}{19.4} \\
\hline & & 23 & 82 & 0 & 0 & $0 \%$ & \\
\hline & & $\%$ & $\%$ & $\%$ & $\%$ & & \\
\hline & Rata-rata & 7.2 & $\begin{array}{c}14 . \\
6\end{array}$ & 0.4 & 0 & 0 & $\begin{array}{c}19.1 \\
2\end{array}$ \\
\hline
\end{tabular}

Tabel 2, respon peserta didik terhadap penerimaan punisment, yang ditunjukkan dari daftar pernyataan berikut ini.

Dimensi kedua ini menyatakan bahwa punisment yang diberikan pada peserta didik bisa membawa pengaruh yang signifikan. Peserta didik menyatakan sangat tidak setuju dengan adanya pelanggaran-pelanggaran yang terjadi. Prosentase tinggi ditunjukkan dari hasil penelitian sebesar 59\% menyatakan sangat tidak setuju jika peserta didik ada yang datang terlambat dan sering mendapat teguran dari Bapak/Ibu guru. 64\% siswa menyatakan setuju bahwa peserta didik merasa malu jika terlalu sering melakukan pelanggaran. Peserta 
didik menyatakan setuju ditunjukkan dengan prosentase tinggi yaitu $73 \%$, dimana setiap pelanggaran harus ada tindak lanjut baik berupa teguran ataupun sanksi.

Tabel 2

Respon peserta didik terhadap punisment yang

\begin{tabular}{|c|c|c|c|c|c|c|c|}
\hline \multirow[t]{2}{*}{ No } & \multirow[t]{2}{*}{ Pernyataan } & SS & $\mathbf{S}$ & $\mathbf{R}$ & TS & STS & \multirow{2}{*}{$\begin{array}{l}\text { Rata- } \\
\text { rata }\end{array}$} \\
\hline & & 5 & 4 & 3 & 2 & 1 & \\
\hline \multirow[b]{2}{*}{1} & \multirow{2}{*}{$\begin{array}{l}\text { Saya datang } \\
\text { terlambat ke } \\
\text { sekolah }\end{array}$} & 0 & 2 & 0 & 13 & 7 & \multirow[b]{2}{*}{8.2} \\
\hline & & $0 \%$ & $9 \%$ & $0 \%$ & $59 \%$ & $32 \%$ & \\
\hline \multirow[b]{2}{*}{2} & \multirow[b]{2}{*}{$\begin{array}{l}\text { Saya } \\
\text { mendapat } \\
\text { teguran dari } \\
\text { Bapak/lbu } \\
\text { Guru karena } \\
\text { datang } \\
\text { terlambat }\end{array}$} & 1 & 16 & 0 & 3 & 7 & \multirow[b]{2}{*}{16.4} \\
\hline & & $5 \%$ & $73 \%$ & $0 \%$ & $14 \%$ & $32 \%$ & \\
\hline \multirow[b]{2}{*}{3} & \multirow[b]{2}{*}{$\begin{array}{l}\text { Saya } \\
\text { mendapat } \\
\text { teguran dari } \\
\text { Bapak/lbu } \\
\text { Guru karena } \\
\text { tidak } \\
\text { menyelesaikan } \\
\text { tugas tepat } \\
\text { pada } \\
\text { waktunya }\end{array}$} & 0 & 16 & 6 & 3 & 2 & \\
\hline & & $0 \%$ & $73 \%$ & $27 \%$ & $14 \%$ & $9 \%$ & 18 \\
\hline \multirow[b]{2}{*}{4} & \multirow{2}{*}{$\begin{array}{l}\text { Saya merasa } \\
\text { malu karena } \\
\text { sering } \\
\text { melakukan } \\
\text { pelanggaran }\end{array}$} & 0 & 14 & 3 & 0 & 5 & \multirow[b]{2}{*}{14} \\
\hline & & $0 \%$ & $64 \%$ & $14 \%$ & $0 \%$ & $23 \%$ & \\
\hline \multirow{3}{*}{5} & \multirow{2}{*}{$\begin{array}{l}\text { Saya akan } \\
\text { berusaha } \\
\text { memperbaiki } \\
\text { kinerja saya } \\
\text { setelah } \\
\text { mendapat } \\
\text { teguran }\end{array}$} & 12 & 10 & 0 & 0 & 0 & \\
\hline & & $55 \%$ & $45 \%$ & $0 \%$ & $0 \%$ & $0 \%$ & 20 \\
\hline & Rata - rata & 2.6 & 11.6 & 1.8 & 3.8 & 4.2 & 15.32 \\
\hline
\end{tabular}

Hasil penelitian menunjukkan bahwa pemberian reward dan punisment dapat memberikan pengaruh besar terhadap motivasi belajar siswa. Strategi guru dalam meningkatkan motivasi atau prestasi peserta didik di sini dengan upaya mencari tahu secara terus menerus bagaimana seharusnya peserta didik itu belajar menggunakan metode yang menarik sesuai dengan situasi dan kondisi peserta didik. Strategi yang tepat akan mempengaruhi proses pembelajaran semakin meningkat secara terus menerus mencapai hasil yang maksimal. Untuk itu guru senantiasa berupaya memotivasi peserta didik agar mereka lebih tertarik untuk mengikuti proses pembelajaran Salah satu caranya dengan cara memberikan reward dan punisment yang bersifat mendidik.

Keampuhan reward dan punisment sebagai alat bantu pendidikan untuk mendapatkan umpan balik dari peserta didik akan terasa jika penerapannya tepat. Terlalu sering memberikan reward dan punisment juga tidak dibenarkan, sebab hal itu akan menjadikan kebiasaan yang kurang menguntungkan dalam kegiatan belajar mengajar. Dikhawatirkan peserta didik giat belajar dan mengerjakan tugas bila hasil kerjanya mendapatkan imbalan dari guru. Tetapi bila tidak ada imbalan peserta didik akan menjadi malas belajar dan mengerjakan tugas. Alangkah bijaksana jika guru tidak memberitahukan terlebih dahulu kepada peserta didik sebelum ia menyelesaikan tugasnya dengan baik. Dengan kata lain reward bisa diberikan secara spontanitas kepada peserta didik yang menunjukkan prestasi kerjanya. Dengan begitu maka peserta didik akan merasa bangga karena hasil kerjanya dihargai baik itu berupa materi ataupun ungkapan. Hal itu juga menjadi dorongan bagi peserta didik lain untuk turut berprestasi dalam belajar dan semua kegiatan sekolah.

\section{SIMPULAN}

Hasil penelitian menjelaskan bahwa pemberian reward dan punisment harus dapat diterapkan secara tepat dan efisein. Dalam arti penerapan reward dan punisment harus disesuaikan dengan situasi dan kondisi peserta didik pada saat itu. Memberikan reward dan punisment dengan mudah akan menghilangkan nilai efektifitasnya, karena peserta didik akan menjadi jenuh dan tidak mempan dengan reward dan punisment tersebut. Oleh karena itu, ada kaitannya antara reward dan punisment yang bersifat mendidik sehingga bisa memberikan motivasi bagi peserta didik yang dalam kondisi prestasi menurun. Melihat hal ini baik guru maupun pihak sekolah berkepentingan untuk mencoba menerapkan pembelajaran dengan menggunakan reward dan punisment. Guna merangsang atau memunculkan motivasi dalam diri peserta didik sehingga hasil belajar yang diperoleh semakin maksimal.

\section{DAFTAR PUSTAKA}

Budiningsih, Asri. (2005).Belajar dan Pembelajaran.Jakarta: Rineka Cipta.

Depdiknas. (2003).Undang-Undang Republik Indonesia No. 20 Tentang Sistem Pendidikan Nasional. Jakarta: Depdiknas. 
Djaali. (2012). Psikologi Pendidikan. Jakarta: Bumi Aksara

Hamalik, Oemar (2000).Psikologi Belajar Mengajar. Bandung : Sinar Baru.

Purwanto, Ngalim. M. (2006).Psikologi Pendidikan.Bandung: Remaja Rosdakarya.

Sanjaya, Wina. (2006). Strategi Pembelajaran. Bandung: Pt. Kencana

Sardiman ( 2007). Interaksi Dan Motivasi Belajar Mengajar.Jakarta: Rajawali Pers.

Slameto. (2010). Belajar dan Faktor-faktor yang mempengaruhinya. Jakarta: PT. Rinela Cipta.

Suryabrata, Sumadi (2005).Psikologi Pendidikan. Jakarta: Raja Grafindo.

Syah, Muhibbin (2008). Psikologi Pendidikan dengan Pendekatan Baru. Bandung: Remaja Rosdakarya.

Uno, Hamzah. B. (2007).Teori Motivasi Dan Pengukurannya Analisis Di Bidang Pendidikan. Jakarta: Bumi Aksara. 